\title{
A new species of Contulma Flint (Trichoptera, Anomalopsychidae) from southeastern Brazil
}

\author{
Gabriela A. Jardim ${ }^{1} \&$ Jorge L. Nessimian ${ }^{1}$
} 'Departamento de Zoologia, Instituto de Biologia, Universidade Federal do Rio de Janeiro, Caixa Postal 68044, Cidade Universitária, $21941-971$ Rio
de Janeiro-RJ, Brazil. gabiajardim@gmail.com; nessimia@acd.ufrj.br

\begin{abstract}
A new species of Contulma Flint (Trichoptera, Anomalopsychidae) from southeastern Brazil. Contulma sana sp. nov. is described and illustrated based on specimens collected in the Rio Macaé Basin, Macaé, Rio de Janeiro State, Brazil. The new species can be distinguished from congeners by the following male genitalia characters: long posterior lobes, dorsomedian processes of segment IX diverging on apical third, and well developed phallotremal sclerite. The female and immature stages are unknown.
\end{abstract}

KEYWORDS. Atlantic Forest; new species; Neotropical Region; taxonomy.

\begin{abstract}
RESUMO. Uma nova espécie de Contulma Flint (Trichoptera, Anomalopsychidae) do Sudeste do Brasil. Contulma sana sp. nov. é descrita e ilustrada com base nos espécimes coletados na Bacia do Rio Macaé, Estado do Rio de Janeiro, Brasil. A nova espécie pode ser distinguida das congêneres pelas seguintes características da genitália masculina: lobos posteriores longos, processos dorsomedianos do segmento IX divergindo a partir do terço apical e esclerito falotremal bem desenvolvido. A fêmea e estágios imaturos são desconhecidos.
\end{abstract}

PALAVRAS-CHAVE. Nova espécie; Mata Atlântica; Região Neotropical; taxonomia.

The family Anomalopsychidae, established by Flint (1981) for two Chilean species previously placed in the Sericostomatidae, is the only caddisfly family fully endemic to the Neotropics (Holzenthal et al. 2007). It contains two genera: the monotypic Anomalopsyche Flint and Contulma Flint, so far with 25 known species (Holzenthal \& Robertson 2006).

The genus Contulma was last revised by Holzenthal \& Flint (1995), who described 18 new species, reviewed the three previously described species, and presented a species phylogeny. Some years later, Holzenthal \& Robertson (2006) described four new species of Contulma, three of them from Brazil. Species are distributed in mountainous areas from Bolivia, Brazil, Chile, Colombia, Costa Rica, Ecuador, and Peru.

Larvae have scraping mandibles, feeding on periphyton. They build cylindrical, slightly curved cases of sand grains. Many species occur in the splash zone of waterfalls and cascades, where they are often found in aquatic moss (Holzenthal et al. 2007). Since adults of the genus usually inhabit small streams in remote mountainous areas and are seldom attracted to light traps, the most common method for collecting adult caddisflies, they are very rarely collected (Holzenthal \& Robertson 2006).

In the present work, we describe and illustrate the adult male of a new species collected at Macaé municipality, Rio de Janeiro State, Brazil.

\section{MATERIAL AND METHODS}

Specimens were collected with Pennsylvania light traps and preserved in $80 \%$ ethanol. To observe the genital structures, the abdomen was removed and cleared in $10 \% \mathrm{KOH}$. Illustrations were made under a stereomicroscope and a compound microscope, both equipped with a camera lucida. Terminology used in the descriptions follows that of Holzenthal \& Flint (1995). Type-specimens were deposited in two collections: Coleção Entomológica Professor José Alfredo Pinheiro Dutra, Departamento de Zoologia, Universidade Federal do Rio de Janeiro, Rio de Janeiro, Brazil (DZRJ) and Museu de Zoologia, Universidade de São Paulo, São Paulo, Brazil (MZSP).

\section{TAXONOMY}

\section{Contulma sana sp. nov.}

(Figs. 1-5)

Description. Adult male. Length of forewing: $3.7-3.9 \mathrm{~mm}$ $(\mathrm{n}=3)$. Forewing color light brown, with small lighter round spots near base; head, thorax, and appendages brown (in alcohol). Foretibial spurs not evident.

Male genitalia. Segment IX in lateral view (Fig. 1) broad, with anterodorsal margin prominently produced anteriorly; posterolateral margin produced medially to form slender, ventrally 



phallotremal sclerite

Figs. 1-5. Contulma sana sp. nov., male. Genitalia: 1, lateral view; 2, dorsal view; 3A, ventral view; $3 \mathrm{~B}$, inset, detail of sternum IX posteromesal projection with apex of most ventral portion omitted in the right side; Phallus: 4 , dorsal view; 5 , lateral view. Scale bars: 0.1 mm.

setose lobe, subequal in length to the height of segment IX; posterodorsally with pair of lightly sclerotized, curved, ventrally directed dorsomesal processes extending beyond posterolateral lobes, with rugose apices; dorsally segment IX highly reduced (Fig. 2); sternum IX in ventral view with sclerotized posteromesal projection (Figs. 1, 3), with mesoapical cleft and bearing about 4 flat, fused, tooth-like setae in the apex (Fig. 3). Inferior appendages apparently fused to base of sternum IX projection. Segment X reduced, entirely membranous. Phallus relatively simple; phallobase sclerotized, tubular (Fig. 4); apex of phallus with membranous grooved dorsal lobe and pair of curved plates forming two parallel channels ventrally (Figs. 4, 5). Phallotremal sclerite well developed, anteriorly round in dorsal view, with horseshoe-like area more strongly sclerotized, and posteriorly bifurcated with elongate arms (Fig. 4).
Female and immature: Unknown.

Holotype male: BRAZIL, Rio de Janeiro: Macaé munici-

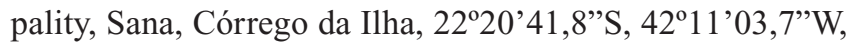
381 m, 19-ii-2009, J. L. Nessimian, G. A. Jardim, I. C. Gonçalves, B. H. L. Sampaio, L. L. Dumas leg., 1 male (DZRJ2379).

Paratypes: same data as holotype, 1 male (MZSP); same data as holotype, except Sana, 2nd order tributary of Rio Boa Sorte, $22^{\circ} 20^{\prime} 34,7^{\prime} \mathrm{S}, 42^{\circ} 11^{\prime} 02,6^{\prime \prime} \mathrm{W}, 373 \mathrm{~m}, 1$ male (DZRJ2380).

Etymology. This species is named in reference to the type locality, Sana, the 6th district of Macaé municipality.

Remarks. Contulma sana probably belongs to the monophyletic group formed by the other four known Brazilian species: C. fluminensis Holzenthal \& Robertson, 2006, C. 
meloi Holzenthal \& Robertson, 2006, C. tripui Holzenthal \& Robertson, 2006, and C. tijuca Holzenthal \& Flint, 1995, with which it shares segment IX ventrally with a posteromesal projection, unique to these species. With the exception of $C$. meloi, these species also share the paired elongate, curved, ventrally directed dorsomedian processes on segment IX. The new species can be distinguished by the long posterior lobes and dorsomedian processes of segment IX diverging on apical third. The well-developed phallotremal sclerite of $C$. sana, with its rather conspicuous shape, is also unique.

\section{ACKNOWLEDGEMENTS}

We thank members of the Laboratorio de Entomologia for aid in collecting specimens. We also thank Dr. Daniela Takiya and anonymous referees for valuable corrections and suggestions on the manuscript. Instituto Brasileiro do Meio Ambiente e dos Recursos Naturais Renováveis (IBAMA) and Instituto
Chico Mendes de Conservação da Biodiversidade (ICMBio) are thanked for issuing collecting permits (IBAMA 14591-2). This study was partially funded by CNPq, FAPERJ, and CAPES.

\section{REFERENCES}

Flint Jr., O. S. 1981. Studies of Neotropical Caddisflies, XXVII: Anomalopsychidae, a new family of Trichoptera, p. 75-85. In: Moretti, G.P. (Ed.) Proceedings of the 3rd International Symposium on Trichoptera. The Hague, Dr. W. Junk Publishers, 494 p.

Holzenthal, R. W. \& O. S. Flint Jr. 1995. Studies of Neotropical Caddisflies, LI: Systematics of the Neotropical Caddisfly Genus Contulma (Trichoptera: Anomalopsychidae). Smithsonian Contributions to Zoology 575: 1-59.

Holzenthal, R. W. \& D. R. Robertson. 2006. Four new species of Contulma from South America (Trichoptera: Anomalopsychidae). Zootaxa 1355: 49-59.

Holzenthal, R. W.; R. J. Blahnik; A. P. Prather \& K. M. Kjer. 2007. Order Trichoptera Kirby, 1813 (Insecta), Caddisflies. Zootaxa 1668: 639698.

Received 14/9/2010; accepted 19/4/2011

Editor: Daniela Maeda Takiya 